\title{
PENGARUH SUHU DAN WAKTU PROSES HARD CHROME PADA PELAT BAJA ST37 TERHADAP KEKERASAN DAN KETEBALAN LAPISAN
}

\author{
Bimo Tri Cahyanto ${ }^{1}$, Samsudin Anis ${ }^{2}$ \\ ${ }^{1,2}$ Program Studi Pendidikan Teknik Mesin Fakultas Teknik Universitas Negeri Semarang \\ Email: bimatri19@gmail.com
}

\begin{abstract}
The thickness and hardness affect the service life of ST37 steels. The temperature and duration of the coating process affect the hard chrome layer's thickness and hardness. The purpose of this study is to determine the effect of temperature and coating duration of the ST37 steel plate using the hard chrome coating method on the thickness and hardness of the coating. This research is an experimental study in which the treatment used is the temperature and duration of the metal plating process with hard chrome. The temperatures used were $45^{\circ} \mathrm{C}$, $50{ }^{\circ} \mathrm{C}$, and $55{ }^{\circ} \mathrm{C}$, and the coating time was 10 minutes, 20 minutes, and 30 minutes. After the hard chrome plating process is complete, the thickness and hardness of each specimen were tested. This research uses descriptive analysis. The results obtained from the thickness test are the highest average layer thickness of 8.9 $\mu \mathrm{m}$ at $45{ }^{\circ} \mathrm{C}, 9.1 \mu \mathrm{m}$ at $50{ }^{\circ} \mathrm{C}$, and $9.2 \mu \mathrm{m}$ at $55^{\circ} \mathrm{C}$, respectively. The coating hardness test result shows an average value of $323.28 \mathrm{VHN}$ at $45^{\circ} \mathrm{C}, 333.01 \mathrm{VHN}$ at $50^{\circ} \mathrm{C}$, and $466.51 \mathrm{VHN}$ at $55^{\circ} \mathrm{C}$, respectively. It can be concluded that the duration of the metal plating process with the controlled temperatures proportionally affects the thickness and hardness of the coating.
\end{abstract}

Keywords: temperature, coating time, hard chrome, ST37 steel

\begin{abstract}
ABSTRAK
Ketebalan dan kekerasan berpengaruh terhadap masa pakai logam baja ST37. Suhu dan lama proses pelapisan mempengaruhi tingkat ketebalan dan kekerasan lapisan hard chrome. Tujuan dari penelitian ini adalah untuk mengetahui pengaruh suhu dan lama pelapisan pelat baja ST37 menggunakan metode pelapisan hard chrome terhadap ketebalan dan kekerasan lapisan. Penelitian ini merupakan penelitian eksperimen di mana perlakuan yang digunakan adalah suhu dan lama proses pelapisan logam dengan hard chrome. Suhu yang digunakan adalah $45^{\circ} \mathrm{C}, 50^{\circ} \mathrm{C}$, dan $55^{\circ} \mathrm{C}$, dan lama pelapisannya yaitu 10 menit, 20 menit, dan 30 menit. Setelah proses pelapisan hard chrome selesai, selanjutnya dilakukan pengujian ketebalan dan kekerasan lapisan pada masing-masing spesimen. Analisis yang digunakan pada penelitian ini adalah analisis deskriptif. Hasil yang didapatkan dari pengujian ketebalan yaitu menghasilkan nilai rata-rata ketebalan lapisan tertinggi sebesar $8,9 \mu \mathrm{m}$ pada suhu $45^{\circ} \mathrm{C}, 9,1 \mu \mathrm{m}$ pada suhu $50^{\circ} \mathrm{C}$, dan $9,2 \mu \mathrm{m}$ pada suhu $55^{\circ} \mathrm{C}$. Hasil pengujian kekerasan lapisan yang didapatkan yaitu menghasilkan nilai rata-rata sebesar $323,28 \mathrm{VHN}$ pada suhu $45^{\circ} \mathrm{C}, 333,01 \mathrm{VHN}$ pada suhu $50^{\circ} \mathrm{C}$, dan $466,51 \mathrm{VHN}$ pada suhu $55^{\circ} \mathrm{C}$. Dapat disimpulkan bahwa semakin lama proses pelapisan logam dengan suhu $45^{\circ} \mathrm{C}, 50^{\circ} \mathrm{C}$, dan $55^{\circ} \mathrm{C}$ maka ketebalan dan kekerasan lapisan akan bertambah.
\end{abstract}

Kata kunci: suhu, lama pelapisan, hard chrome, baja ST37

\section{PENDAHULUAN}

Dalam kehidupan sehari-hari, besi dan campurannya sudah sangat banyak digunakan baik untuk peralatan rumah tangga, industri, kedokteran, dan lain-lain karena sifatnya yang kuat dan dapat menahan panas. Harganya yang terjangkau membuat material ini banyak ditemui di sekitar kita. Namun masalah yang sering ditemui adalah korosi pada material yang menyebabkan peralatan menjadi berumur pendek sehingga menambah banyak biaya yang harus dikeluarkan. Korosi merupakan penurunan mutu logam yang diakibatkan karena reaksi kimia atau elektrokimia dengan lingkungan. Korosi ini menjadi beban dalam industri, tidak hanya penurunan daya guna dari logam, namun korosi juga mengakibatkan kerugian dari segi 
penampilan. Korosi tidak dapat dicegah namun dapat dikendalikan. Salah satu cara pengendaliannya yaitu dengan memberi lapisan pelindung pada permukaan logam dasar, diantaranya secara elektroplating. Selain tujuan tersebut, elektroplating juga mampu meningkatkan mutu dan nilai estetika pada produk (Danang, 2013).

Pelapisan logam mulai banyak digunakan sebagai cara untuk mencegah logam dari korosi. Selain mencegah korosi, pelapisan logam mulai dikembangkan untuk mencegah logam dari keausan, mempertebal lapisan permukaan logam dan memperkuat logam (Yusep, 2016). Pelapisan logam dengan cara elektroplating mempunyai banyak jenis, yaitu elektroplating seng, tembaga, krom, dan lain-lain. Pada elektroplating krom juga terbagi menjadi dua metode, yaitu krom dekoratif dan krom keras (hard chrome) (Azhar, 2014). Pada metode Hard Chrome sering diaplikasikan pada bidang teknik untuk membuat as hydraulic, as piston, shaft, piston gas karburator, senjata api, knalpot, dan lain- lain. Tujuan dari pelapisan hard chrome adalah sebagai pelapis baja dan meningkatkan ketahanan logam terhadap korosi, melapisi permukaan logam agar lebih keras, meningkatkan ketahanan logam terhadap gesekan dan memperbaiki kehalusan permukaan yang dilapisi. Penyebab dari terjadinya goresan/keausan pada permukaan logam adalah rusaknya permukaan logam, umumnya melibatkan kehilangan material yang progresif akibat adanya gesekan antara permukaan logam (Budi, 2017). Pelapisan hard chrome dilakukan untuk memanfaatkan kelebihan sifat yang dimiliki unsur krom untuk mendapatkan keuntungan. Keuntungan tersebut berupa sifat tahan terhadap panas, memiliki koefisien gesek yang rendah, menghindari korosi. Untuk mendapatkan hasil tersebut, maka banyak faktor yang mempengaruhi. Diantaranya adalah arus listrik, koefisien larutan, jarak anoda dan katoda, tegangan listrik, suhu, dan lama proses pelapisan.

Penelitian tentang suhu dan waktu pelapisan pernah dilakukan oleh Dewi (2016) dengan memvariasikan suhu $45^{\circ} \mathrm{C}, 55^{\circ} \mathrm{C}$, dan $65^{\circ} \mathrm{C}$ dan lama pelapisan 10 menit, 20 menit, dan 30 menit di mana diperoleh hasil pengamatan yaitu perbedaan waktu pelapisan pada baja karbon rendah dengan tembaga secara elektroplating dengan variasi suhu dan waktu menghasilkan lapisan yang tidak sama rata, namun tidak terlihat hubungan yang gradual antara suhu dengan waktu pelapisan dalam elektroplating baja karbon rendah oleh tembaga.

Hasil penelitian dari Sudarmono (2013) terkait pengaruh variasi temperatur proses pelapisan nikel-khrom terhadap kualitas ketebalan dan kekerasan pada baja ST40 dengan menggunakan variasi suhu $40^{\circ} \mathrm{C}, 45^{\circ} \mathrm{C}, 50^{\circ} \mathrm{C}$, $55^{\circ} \mathrm{C}$, dan $60^{\circ} \mathrm{C}$ dijelaskan bahwa spesimen awal memiliki tingkat kekerasan sebesar 254.3 HB 30. Setelah dilapisi Ni, meningkat secara signifikan sebesar 337 HB 30. Hasil uji kekerasan mempunyai nilai optimum pada spesimen ST40$\mathrm{Ni}-\mathrm{Cr}$ dengan temperature $55^{\circ} \mathrm{C}$ sebesar $354 \mathrm{HB}$ 30. Sedangkan pada temperatur $60^{\circ} \mathrm{C}$ terjadi penurunan nilai kekerasan menjadi 345,3 HB 30. Hal ini menunjukkan bahwa pada temperatur elektroplating $55^{\circ} \mathrm{C}$ memberikan konduktivitas arus terbaik dan mobilitas ion- ion krom menempel pada permukaan spesimen, sehingga lapisan krom lebih padat dan menyebabkan kerapatan permukaan pada spesimen meningkat.

Hasil penelitian yang dilakukan Andhi dkk (2018) tentang variasi suhu elektroplating terhadap ketebalan lapisan nikel baja ST37, dengan memvariasikan suhu $60^{\circ} \mathrm{C}, 70^{\circ} \mathrm{C}$, dan $80^{\circ} \mathrm{C}$, diperoleh hasil bahwa suhu pelapisan berpengaruh terhadap ketebalan lapisan nikel secara elektroplating. Di mana semakin tinggi suhu pencelupan maka sebakin tebal lapisan tersebut, bentuk dan ukuran benda juga dapat mempengaruhi hasil ketebalan lapisan.

Hasil penelitian yang dilakukan oleh Budi (2017) tentang pengaruh hard chrome pada peningkatan kekerasan baja, dapat disimpulkan bahwa peningkatan pelapisan hard chrome naik linear sebanding dengan durasi pelapisan. Berdasarkan dari hasil penelitian yang telah dijelaskan di atas, maka penulis tertarik untuk menganalisis tentang pengaruh variasi suhu dan 
lama proses hard chrome pada pelat baja ST37 terhadap ketebalan dan kekerasan lapisan.

\section{METODE}

Penelitian ini merupakan penelitian eksperimen, di mana parameter yang mempengaruhi hasil dari tingkat ketebalan dan kekerasan lapisan adalah suhu dan lama pelapisan. Variasi yang digunakan dalam penelitian ini adalah variasi suhu $45^{\circ} \mathrm{C}, 50^{\circ} \mathrm{C}$, dan $55^{\circ} \mathrm{C}$ dan lama pelapisan 10 menit, 20 menit, dan 30 menit.

Teknik analisis data yang digunakan dalam penelitian ini adalah analisis statistik deskriptif yang diperoleh dari hasil pengujian. Penelitian dilakukan dengan menggunakan alat Generator DC untuk proses elektroplating. Bahan yang digunakan dalam penelitian ini adalah logam baja ST37.

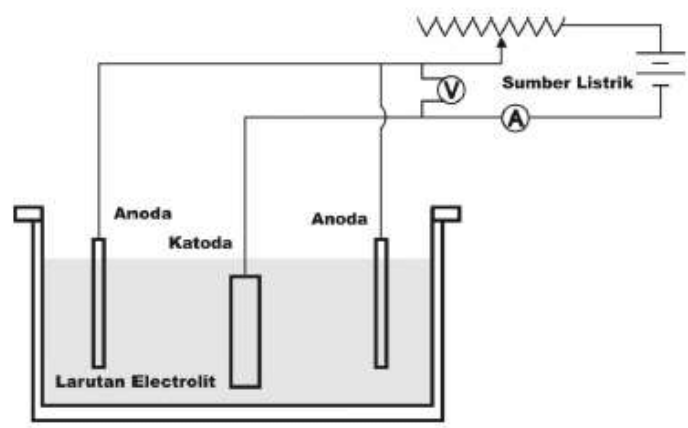

Gambar 1. Skema Elektroplating

Proses awal yaitu membuat spesimen uji dari bahan Baja ST37 dengan ukuran 100 mm x $20 \mathrm{~mm}$ x $2 \mathrm{~mm}$. Selanjutnya dilanjutkan dengan proses pre-treatment yaitu pembersihan spesimen menggunakan ampelas dan mesin poles untuk menghilangkan kotoran, dilanjut dengan proses elektroplating, dimana benda kerja dicelupkan kedalam larutan $\mathrm{CrO}_{3}$ yang dialiri listrik. Setelah itu benda kerja di lakukan pemolesan untuk mendapatkan hasil yang maksimal.

Pengujian kekerasan lapisan dilakukan dengan menggunakan alat Vickers Hardness Test TH170, yaitu dengan meletakkan benda kerja pada ragum, lalu ditekan dengan penekanan 5 grf selama 10 detik pada 3 titik untuk masing- masing spesimen. Lakukan hal yang sama pada masing-masing spesimen. Langkah selanjutnya adalah melakukan pengujian ketebalan dengan menggunakan alat Microscope Olympus C$35 A D-4$, di mana benda kerja diletakkan pada ragum dengan posisi permukaan sisi spesimen menghadap lensa dengan pembesaran 100x pada 3 titik untuk masing-masing spesimen dan lakukan hal tersebut pada masing-masing spesimen.

\section{HASIL DAN PEMBAHASAN}

Pengambilan nilai kekerasan lapisan dilakukan dengan menggunakkan alat uji kekerasan Vickers Hardness Test TH 170 dengan pembebanan sebesar 5 grf selama 10s. Penekanan dilakukan pada setiap spesimen yang diambil secara acak.

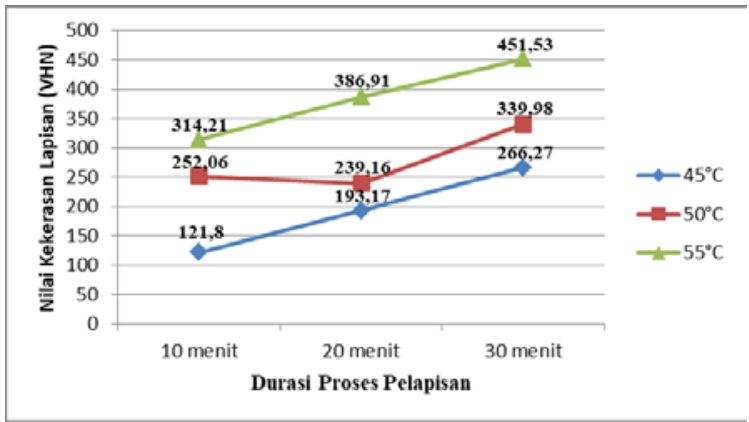

Gambar 2. Grafik Rata-Rata Kekerasan Lapisan pada Suhu $45^{\circ} \mathrm{C}, 50^{\circ} \mathrm{C}$, dan $55^{\circ} \mathrm{C}$

Grafik nilai rata-rata kekerasan lapisan menunjukkan bahwa lama pelapisan 30 menit pada masing-masing suhu $45^{\circ} \mathrm{C}, 50^{\circ} \mathrm{C}$, dan $55^{\circ} \mathrm{C}$ memiliki nilai kekerasan paling signifikan bila dibandingkan lama pelapisan 10 menit dan 20 menit pada masing-masing suhu $45^{\circ} \mathrm{C}, 50^{\circ} \mathrm{C}$, dan $55^{\circ} \mathrm{C}$. Hal tersebut terjadi karena beberapa faktor, yaitu: (1) faktor manusia pada saat proses pre-treatment dan post-treatment menyebabkan kekerasan permukaan pada spesimen berbeda satu sama lain; (2) faktor konsentrasi larutan pada saat proses pengadukan mengalami perubahan sehingga menyebabkan ion-ion logam pada larutan mengalami kenaikan kecepatan reduksi menuju katoda, sehingga ion-ion krom yang menempel pada katoda lebih rata, tebal, 
keras, dan halus. Dari fenomena tersebut dapat disimpulkan bahwa tingkat kekerasan mengalami kenaikan yang cukup signifikan pada tiap suhu $45^{\circ} \mathrm{C}, 50^{\circ} \mathrm{C}$, dan $55^{\circ} \mathrm{C}$ pada lama pelapisan 10 menit, 20 menit, dan 30 menit.

Dari data hasil pengujian di atas diperoleh hasil pengujian kekerasan terhadap specimen yang telah dilapisi hard chrome memperlihatkan bahwa suhu dan lama proses pelapisan berpengaruh terhadap hasil dari nilai kekerasan lapisan, hal ini dikarenakan semakin besar dan lama proses pelapisan maka nilai kekerasan juga akan naik.

Pengambilan nilai ketebalan lapisan Hard Chrome dapat diperoleh dengan cara pengukuran dengan menggunakan alat uji ketebalan Microscope Olympus C35AD-4 dengan pembesaran $100 \mathrm{x}$ dan diukur ketebalan lapisan pada masing-masing spesimen secara acak.

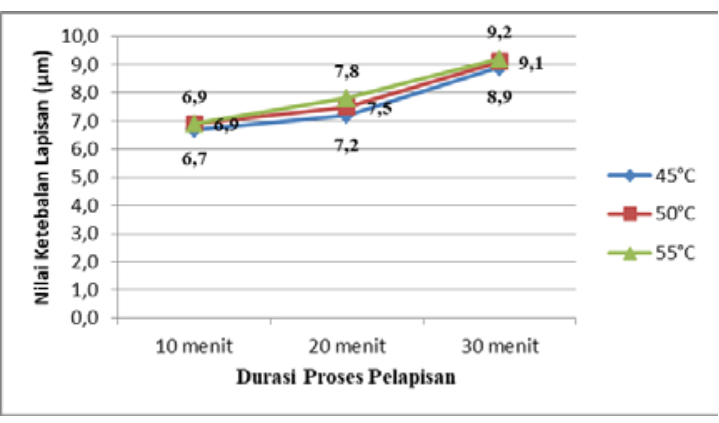

Gambar 3. Grafik nilai rata-rata ketebalan lapisan pada suhu $45^{\circ} \mathrm{C}, 50^{\circ} \mathrm{C}$, dan $55^{\circ} \mathrm{C}$

Grafik nilai rata-rata ketebalan lapisan menunjukkan bahwa lama pelapisan 30 menit pada masing-masing suhu $45^{\circ} \mathrm{C}, 50^{\circ} \mathrm{C}$, dan $55^{\circ} \mathrm{C}$ memiliki nilai kekerasan paling signifikan bila dibandingkan lama pelapisan 10 menit dan 20 menit pada masing-masing suhu $45^{\circ} \mathrm{C}, 50^{\circ} \mathrm{C}$, dan $55^{\circ} \mathrm{C}$. Hal tersebut terjadi karena beberapa faktor, yaitu: (1) faktor manusia pada saat proses pre-treatment dan post-treatment menyebabkan kekerasan permukaan pada spesimen berbeda satu sama lain; dan (2) faktor konsentrasi larutan pada saat proses pengadukan mengalami perubahan sehingga menyebabkan ion-ion logam pada larutan mengalami kenaikan kecepatan reduksi menuju katoda, sehingga ion-ion krom yang menempel pada katoda lebih rata, tebal, keras, dan halus.

Dari fenomena tersebut dapat disimpulkan bahwa tingkat kekerasan mengalami kenaikan yang cukup signifikan pada tiap suhu $45^{\circ} \mathrm{C}, 50^{\circ} \mathrm{C}$, dan $55^{\circ} \mathrm{C}$ pada lama pelapisan 10 menit, 20 menit, dan 30 menit. Dari data hasil pengujian ketebalan, dapat disimpulkan bahwa suhu dan lama proses pelapisan hard chrome berpengaruh terhadap hasil dari nilai ketebalan lapisan, dimana semakin besar suhu dan lama pelapisan maka tingkat ketebalan juga akan meningkat.

Penelitian ini membuktikan bahwa suhu dan lama pelapisan hard chrome dapat mempengaruhi nilai kekerasan dan ketebalan lapisan. Pada tingkat kekerasan lapisan, dapat ditarik kesimpulan bahwa semakin besar suhu dan lama pelapisan yang digunakkan maka akan semakin keras pula hasil pelapisan yang didapatkan. Hal tersebut dibuktikan dengan hasil pelapisan pada suhu $50^{\circ} \mathrm{C}$ dengan lama pelapisan 30 menit menghasilkan nilai kekerasan sebesar 339,98 VHN. Pada tingkat ketebalan lapisan, dapat ditarik kesimpulan bahwa semakin besar suhu dan lama pelapisan yang digunakan, maka akan semakin tebal pula hasil pelapisan yang didapatkan. Hal tersebut dibuktikan dengan hasil pelapisan pada suhu $50^{\circ} \mathrm{C}$ dengan lama pelapisan 30 menit menghasilkan nilai ketebalan sebesar $9.1 \mu \mathrm{m}$.

\section{SIMPULAN}

Berdasarkan hasil dari data metode pelapisan hard chrome pada pelat baja ST37 yang didapatkan dari pengujian variasi suhu dan lama proses pelapisan terhadap ketebalan dan kekerasan lapisan dapat diambil kesimpulan sebagai berikut:

1. Suhu dan lama pelapisan pada proses hard chrome pada pelat baja ST37 berpengaruh terhadap nilai ketebalan lapisan. Semakin 
besar suhu dan lama proses pelapisan maka tingkat ketebalan lapisan akan semakin tebal. Pada penelitian ini ketebalan yang optimal terjadi pada pelapisan dengan suhu $50^{\circ} \mathrm{C}$ dan lama pelapisan 30 menit sebesar $9.1 \mu \mathrm{m}$.

2. Suhu dan lama pelapisan pada proses hard chrome pada pelat baja ST37 berpengaruh terhadap nilai kekerasan lapisan. Semakin besar suhu dan lama proses pelapisan maka tingkat kekerasan lapisan akan semakin keras, pada penelitian ini tingkat kekerasan yang optimal terjadi pada pelapisan dengan suhu $50^{\circ} \mathrm{C}$ dan lama pelapisan 30 menit sebesar 339,98 VHN.

\section{DAFTAR RUJUKAN}

Andhi Setyo Pamungkas, Hani Prasetyo, Nani Mulyaningsih. 2018. Pengaruh variasi temperatur elektroplating terhadap ketebalan lapisan nikel baja ST37. Jurnal Mechanical Engineering Research Collection. Volume 1. Nomor 1, 1-3.

Azhar A Saleh. 2014. Electroplating teknik pelapisan logam dengan cara listrik. Bandung: Yrama Widya.

Budi Setyahandana \& Yohanes Eko Christianto. 2017. Pengaruh hard chrome plating pada peningkatan kekerasan baja komponen kincir. Media Teknika Jurnal Teknologi. Volume 12 Nomor 1, 26-35.

Danang Tarwijayanto, Wahyu Purwo Raharjo, Teguh Triyono. 2013. Pengaruh arus dan waktu pelapisan hard chrome terhadap ketebalan lapisan dan tingkat kekerasan mikro pada plat baja karbon rendah AISI 1026 dengan menggunakan $\mathrm{CrO}_{3} 250 \mathrm{gr} / \mathrm{lt}$ dan $\mathrm{H}_{2} \mathrm{SO}_{4} \quad 2,5 \quad \mathrm{gr} / \mathrm{lt}$ pada proses elektroplating. Jurnal Mekanika. Volume 11. Nomor 2, 109-115.

Dewi Sasmita. 2016. Pengaruh suhu dan waktu pelapisan tembaga pada baja karbon rendah secara elektroplating terhadap korosi. Jurnal EKSAKTA. Volume 2. Nomor 1, 6165.

Sudarmono Rizki Yulianto \& Edi Widodo. 2013. Analisa pengaruh variasi temperatur proses pelapisan nikel khrom terhadap kualitas ketebalan dan kekerasan pada baja ST40. Procceding Call of Paper. Volume 2. Nomor 1, 145-149.

Yusep Sukrawan. 2016. Analisis variasi waktu proses hard chrome terhadap kekerasan dan ketebalan lapisan pada besi cor kelabu. Jurnal Torsi. Volume 1. Nomor 1, 1-9. 